\title{
Improving Students' Writing Skill by Using Wholesome Scattering Game
}

\author{
Dina Novrieta ${ }^{1}$, Sopi Nurisa ${ }^{2}$ \\ ${ }^{1}$ IAIN Syaikh Abdurrahman Siddik Bangka Belitung \\ ${ }^{2}$ IAIN Syaikh Abdurrahman Siddik Bangka Belitung
}

\begin{tabular}{ll}
\hline \hline & ABSTRACT \\
\cline { 2 - 2 } Keywords: & The aim of this research is to describe the implementation of Wholesome \\
Writing Skills & Scattering Game in improving students' writing skills on descriptive text and to \\
Wholesome Scattering Game & find out whether there is a significant difference between students who were \\
Descriptive Text & taught by using Wholesome Scattering Game and the students who were not. \\
& This research used quantitative approach focusing on experimental research \\
& which was conducted at SMAN 2 Sungaiselan, Bangka Belitung Province in \\
& academic year 2019/2020. The researcher used purposive sampling technique \\
& and two classes were taken as samples, with 69 students (35 students for the \\
& control group and 34 students for the experimental). The result of the test was \\
& analyzed by using statistical analysis of Paired sample t-test and Independent \\
& sample t-test. The finding showed that the students who were taught by using \\
& Wholesome Scattering Game got higher score than those who were taught by \\
& using non-Wholesome Scattering Game. It means that the alternative \\
& hypothesis (Ha) was accepted, while the null hypothesis (Ho) was rejected. It \\
& could be concluded that there was a significant difference between students who \\
& were taught by using Wholesome Scattering Game and the students who were \\
& taught without using Wholesome Scattering Game.
\end{tabular}

\section{Correspondence:}

Dina Novrieta,

Email: dinan11@gmail.com

\section{Introduction}

Students of the 10th grade got some problems in writing the text. Based on the study on a preliminary test and observation of the students, the researcher found that the students had low comprehension in writing descriptive texts. In general, this can be caused by EFL learners' problem of having low vocabulary mastery in Indonesia (Indrawati \& Resti, 2020). The problems faced by the students and the teacher were known in some indicators, as follows: the researcher found that $80 \%$ of 212 students had difficulties in writing descriptive text. From the result of the test, researcher found X MIPA-1 and X MIPA-2 got the lowest scores, students experienced difficulties in some aspects of writing on descriptive text and based on the interview with the teacher of English, the problems were when teaching and learning descriptive text in the classroom, the students showed less of lexico grammatical features of descriptive text and they got difficulties to use action verbs and adjectives in writing descriptive text. Moreover, they did not have a good vocabulary mastery.

Writing descriptive text should be offered by the teacher through interesting way, because it could ease and comfort the students in writing the sentences. One of the interesting strategies in writing descriptive text is by using game. Talak-Kiryk states that games are fun activities that promote interaction, thinking, learning, and problem solving strategies. (Talak-Kiryk, 2010) In other words, using game as a teaching strategy will help the students to learn the complicated process of writing in interesting way.

Therefore, the researcher applied wholesome scattering game as one of the games believed to be able to improve students' writing skill, especially in descriptive text. Researcher's belief was based on the result of some previous studies. A study by Hami found that Wholesome Scattering Game can be used to teach writing descriptive text for seventh grade students (Hami, 2011). Other studies proved that Wholesome Scattering Game is a technique for teaching that gave a good effect on the ability of high school students in 
writing descriptive text (Pratiwi, 2016; Agustina, 2018; KURNIAWATI, 2015; Sinulingga, 2015). The implementation of wholesome scattering game is: (a) three students are asked to write vocabularies which are dictated by the teachers on the board in unusual shape; (b) Both the teacher and students correct the letter together and the students imitate the vocabularies the teacher spelt; (c) The students discuss in a group; (d) They arrange and organize the vocabularies to be a descriptive text; (e) At last, the students present their task in front of the class; (f) After that, the teacher gives a feedback on the teaching learning process. So, as stated above, basically there were six steps of implementing wholesome scattering game. The studies by Santika, Juvrianto and Nisa' proved that Wholesome Scattering Game is a technique for teaching that gave a positive effect on the ability of tenth grade students in writing descriptive and procedure text. Based on the result of this study, it could be seen that the students who were taught by using Wholesome Scattering Game got higher score than those who were taught by using non-Wholesome Scattering Game. It could be seen from the result of the mean score of post-test in the experimental group was higher (76.83) than the mean score in control group (66.81).

Based on the problems above, the researcher was interested in proposing a study entitled, Improving Students' Writing Skill by Using Wholesome Scattering Game of the Tenth Grade Students of SMAN 2 Sungaiselan.

Therefore, the writer conducted this research to know the implementation of Wholesome Scattering game strategy in increasing students' writing skill in writing descriptive text to the 10th grade students of SMAN 2 Sungaiselan and to examine there is any significant differences in writing skill between the students who are taught by using Wholesome Scattering game strategy and the students who are taught without Wholesome Scattering game strategy in writing students' achievement in writing descriptive text to the 10th grade students of SMAN 2 Sungaiselan.

\section{Method}

The population of this study was all of the 10th grade students of the high school with 212 students. It consisted of six classes. It could be seen in the following table:

In this research, the researcher used nonprobability sampling technique. In nonprobability sampling, the researcher selects individuals because they are available, convenient, and represent some characteristics the investigator seeks to study. (Sugiyono, 2007) One kind of Non-probability sampling is purposive sampling for conducting the research. Purposive sampling is a sampling technique which takes the sample with certain considerations. In this case, the considerations were:

1. The English teacher's suggestion.

2. The result from preliminary test stated that there were two classes who got the lowest scores from the preliminary test, they were X-MIPA 1 and X-MIPA 2. X-MIPA 1 got the same score as X-MIPA 2. Then the researcher determined that X-MIPA 1 as experimental group and X-MIPA 2 as control group.

However, the population in this research was 212 students, so the researcher would like to take two classes of population as a sample.

The Sample of the Study

\begin{tabular}{|c|c|c|c|c|c|}
\hline No. & Group & Class & Male & Female & Total \\
\hline 1 & The Experimental Group & X MIPA-1 & 13 & 21 & 34 \\
\hline 2 & The Control Group & X MIPA-2 & 16 & 19 & 35 \\
\hline \multicolumn{2}{|c|}{ Total } & \multicolumn{4}{|c|}{$\mathbf{6 9}$} \\
\hline
\end{tabular}

Source: SMAN 2 Sungaiselan

In this study, the researcher used three instruments to collect the data, they are test, observation, and documentation. In conducting this research, it took 90 minutes for every meeting. There are some procedures to implement Wholesome Scattering Game, as stated below. 


\begin{tabular}{|c|c|c|c|}
\hline No. & Writing Activity & Teacher's Activity & Student's Activity \\
\hline \multirow[t]{2}{*}{1.} & \multirow[t]{2}{*}{ Pre- Activity } & - Teacher greets the students. & - Students answer the greeting. \\
\hline & & - Teacher gives lead in activities. & $\begin{array}{l}\text { - Students answer the questions from lead } \\
\text { in activities. }\end{array}$ \\
\hline \multirow[t]{7}{*}{2.} & \multirow[t]{7}{*}{$\begin{array}{l}\text { a. Planning/Pre- } \\
\text { writing }\end{array}$} & $\begin{array}{l}\text { 1. Teacher asks three to five students to } \\
\text { come to the board. Their task is to } \\
\text { write down words you dictate. (in a } \\
\text { good class, ask a student to dictate). } \\
\text { Each student writes each word so } \\
\text { that each word is written as many } \\
\text { times as there are students at the } \\
\text { board. They scatter these words at } \\
\text { random all over the board, and try } \\
\text { to arrange the words in unusual } \\
\text { ways. Some will be written } \\
\text { horizontally, other vertically, others } \\
\text { in shapes, others upside down. (e.g: } \\
\text { kind, generous, white skin, pointed } \\
\text { nose, long hair, and pretty) Do not } \\
\text { comment on spelling at this stage. } \\
\text { Some students will change their } \\
\text { spelling as they observe how the } \\
\text { student next to them has spelt a } \\
\text { word or as they are corrected by } \\
\text { others in the class. }\end{array}$ & $\begin{array}{l}\text { 1. Three to five students come to the } \\
\text { board. Their task is to write down } \\
\text { words you dictate. (in a good class, ask } \\
\text { a student to dictate). Each student } \\
\text { writes each word so that each word is } \\
\text { written as many times as there are } \\
\text { students at the board. They scatter } \\
\text { these words at random all over the } \\
\text { board, and try to arrange the words in } \\
\text { unusual ways. Some will be written } \\
\text { horizontally, other vertically, others in } \\
\text { shapes, others upside down. The other } \\
\text { students should not comment on } \\
\text { spelling at this stage. Some students } \\
\text { will change their spelling as they } \\
\text { observe how the student next to them } \\
\text { has spelt a word or as they are } \\
\text { corrected by others in the class. }\end{array}$ \\
\hline & & $\begin{array}{l}\text { 2. While the students at the board are } \\
\text { doing this, the teacher asks those } \\
\text { students who seated can produce } \\
\text { their own arrangements of the } \\
\text { words either on paper or in } \\
\text { notebooks. }\end{array}$ & $\begin{array}{l}\text { 2. While the students at the board are } \\
\text { doing this, those students who seated } \\
\text { can produce their own arrangements of } \\
\text { the words either on paper or in } \\
\text { notebooks. }\end{array}$ \\
\hline & & $\begin{array}{l}\text { 3. When the teacher has finished } \\
\text { dictating the words, the teacher } \\
\text { asks the students who are at the } \\
\text { board return to their seats. }\end{array}$ & $\begin{array}{l}\text { 3. When the teacher has finished dictating } \\
\text { the words, the students who are at the } \\
\text { board return to their seats. }\end{array}$ \\
\hline & & $\begin{array}{l}\text { 4. Teacher asks if anyone in the class } \\
\text { thinks they have produced a } \\
\text { particularly unusual arrangement of } \\
\text { the words. If there are volunteers, } \\
\text { the teacher asks them to display } \\
\text { their arrangements. }\end{array}$ & $\begin{array}{l}\text { 4. Students are asked if anyone in the } \\
\text { class thinks they have produced a } \\
\text { particularly unusual arrangement of } \\
\text { the words. If there are volunteers, the } \\
\text { teacher asks them to display their } \\
\text { arrangements. }\end{array}$ \\
\hline & & $\begin{array}{l}\text { 5. Teacher goes over the words on the } \\
\text { board, eliciting correct spelling and } \\
\text { meaning. }\end{array}$ & $\begin{array}{l}\text { 5. Students pay attention while the } \\
\text { teacher goes over the words on the } \\
\text { board, eliciting correct spelling and } \\
\text { meaning. }\end{array}$ \\
\hline & & $\begin{array}{l}\text { 6. Teacher asks the students, in pairs, } \\
\text { to write as many sentences as } \\
\text { possible using the words on the } \\
\text { board. They should try to put more } \\
\text { than one of the words in each } \\
\text { sentence. Tell them that they have } \\
\text { only three minutes for this. }\end{array}$ & $\begin{array}{l}\text { 6. Students are asked, in pairs, to write as } \\
\text { many sentences as possible using the } \\
\text { words on the board. They should try to } \\
\text { put more than one of the words in } \\
\text { each sentence. They have only three } \\
\text { minutes for this. }\end{array}$ \\
\hline & & $\begin{array}{l}\text { 7. Teacher stops them when the time } \\
\text { is up and ask pairs to tell you how } \\
\text { many sentences they have } \\
\text { succeeded in writing. }\end{array}$ & $\begin{array}{l}\text { 7. The students are asked to stop when } \\
\text { the time is up and pairs are asked to } \\
\text { tell the teacher how many sentences } \\
\text { they have succeeded in writing. }\end{array}$ \\
\hline
\end{tabular}




\begin{tabular}{|c|c|c|c|}
\hline & & $\begin{array}{l}\text { 8. Teacher asks each pair to read out } \\
\text { its best sentence. }\end{array}$ & $\begin{array}{l}\text { 8. Each pair is asked to read out its best } \\
\text { sentence. }\end{array}$ \\
\hline & & $\begin{array}{l}\text { 9. Teacher asks the class to predict the } \\
\text { content of the text they are about to } \\
\text { read. }\end{array}$ & $\begin{array}{l}\text { 9. Students are asked to predict the } \\
\text { content of the text they are about to } \\
\text { read. }\end{array}$ \\
\hline & & $\begin{array}{l}\text { 10.Teacher gives brief explanation } \\
\text { about descriptive text and its social } \\
\text { function, generic structures and } \\
\text { language features. }\end{array}$ & $\begin{array}{l}\text { 10. Students pay attention to the teacher's } \\
\text { explanation. }\end{array}$ \\
\hline & b. Drafting & $\begin{array}{l}\text { 1. Teacher asks the students to make } \\
\text { first draft in a form of paragraph } \\
\text { using the words and sentences they } \\
\text { have written before. }\end{array}$ & $\begin{array}{l}\text { 1. Students make the first draft in a form } \\
\text { of paragraph using the words and } \\
\text { sentences they have written before. }\end{array}$ \\
\hline & $\begin{array}{l}\text { c. Editing and } \\
\text { Final Version }\end{array}$ & $\begin{array}{l}\text { 1. Teacher shares and focuses on some } \\
\text { students general mistakes in } \\
\text { mechanic aspect. }\end{array}$ & $\begin{array}{l}\text { 1. Students pay attention to the teacher's } \\
\text { explanation. }\end{array}$ \\
\hline & & $\begin{array}{l}\text { 2. Teacher turns back the students' } \\
\text { draft. }\end{array}$ & 2. Students take their draft. \\
\hline & & $\begin{array}{l}\text { 3. Teacher asks the students to revise } \\
\text { and edit the students' draft into a } \\
\text { good paragraph. (in pair) }\end{array}$ & $\begin{array}{l}\text { 3. Students revise and edit their draft. (in } \\
\text { pair) }\end{array}$ \\
\hline & & $\begin{array}{l}\text { 4. Teacher asks the students to make } \\
\text { final version or second draft of their } \\
\text { writing that ready to be submitted } \\
\text { and scored by the teacher. }\end{array}$ & $\begin{array}{l}\text { 4. Students make the final version or the } \\
\text { second draft of their writing that ready } \\
\text { to be submitted and scored by the } \\
\text { teacher. }\end{array}$ \\
\hline 3. & Post- Activity & $\begin{array}{l}\text { - Teachers asks the students to submit } \\
\text { their work. }\end{array}$ & - The students submit their work. \\
\hline & & - Teachers says goodbye. & - Students say goodbye. \\
\hline
\end{tabular}

Test was analyzed by statistical analysis while data from observation was analyzed by non-statistical analysis. Then, the statistical data was measured by using SPSS 26.0 and non-statistical data was analyzed by descriptive analysis.

There were five aspects in writing that were scored, they were content, organization, vocabulary, language use, and mechanic. In analyzing the data, the researcher used SPSS 26.0 in calculating the data. The statistical strategy which is used by researcher was independent sample t-test. This strategy was used to compare the result of pre-test and post-test between experimental and control group. The researcher used Pearson Product Moment Correlation Coefficient of SPSS (Statistical Package for the Social Science) 26 in processing the data to know the validity and reliability of the test items.

This research used a quantitative method. Quantitative research stressed the relationship between manipulated (independent variable) and characteristic of the participant (dependent variable) which is randomly selected the participants and manipulating variables. (Tavakoli, 2012) Meanwhile, this research is an experimental research. Experimental research is a study that strictly adheres to a scientific research design. It includes a hypothesis, a variable that can be manipulated by the researcher, and variables that can be measured, calculated and compared. Most importantly, experimental research is completed in a controlled environment. The researcher collects the data and result will either support or reject the hypothesis. This method of research is referred to a hypothesis testing or a deductive research method (E. R. Babbie, 2016).

In this study, the researcher used a quasi-experimental design. Quasi-experimental designs differ from true experimental designs in two ways. First, participants are not randomly selected from a specified population. Second, participants are not randomly assigned to experimental and control groups. (Martella, Nelson, \& Marchand-Martella, 1999) The researcher conducted the research by using one of the quasiexperimental designs: pretest-posttest nonequivalent control group design. In the experimental group, the 
researcher taught using Wholesome Scattering game strategy, while in the control group the researcher taught using non Wholesome Scattering game strategy.

The students' writing skill test was designed to cover a range of abilities or sub skills. It was scored in term of five aspects: content, organization, vocabulary, language use, and mechanic aspects.

In the technique of data analysis, the researcher used SPSS (Statistical Package for the Social Science) 26 in calculating the data. The statistical method used by researcher was independent sample t-test. This method used to compare the result of pre-test and post-test between experiment and control group. According to Sugiyono, independent sample t-test used to compare the result of pre-test and post-test between experiment and control group. (Sugiyono, 2007b) Therefore, the researcher used independent sample t-test to find out the significant difference in writing skills between the experimental group and the control group. (Hatch \& Farhady, 1982) Therefore, it was used to know whether there was a significant difference between the students' pre-test score and their post-test score.

This research used observation sheet by Zainal Asril, the aspects of the students' activities are cooperation, participation, and concept aspects. The data of observation was analyzed with non-statistical analysis. Data observation was described in descriptive percentage form, it was used to explain the students' activities individually and group during the implementation of Wholesome Scattering game strategy in improving students' writing skills in descriptive texts. The calculation of observation percentage is as follows:

Number of students who...

Total number of students

$$
\text { X } 100 \%
$$

\section{Results and Discussion}

The researcher conducted this research for fourteen meetings. First meeting was used to give pre-test and the last meeting was used for post- test. Then, the researcher applied Wholesome Scattering Game for twelve meetings. It is used to know whether the implementation of Wholesome Scattering Game was effective or not for improving students' writing skills in descriptive text.

The interpretation of this study consisted of two parts; they were (1) the interpretation of the implementation and observation, and (2) the interpretation of the test comparative analysis result.

\section{The Analysis of Implementation and Observation}

After accomplishing the implementation and the observation in this study, the researcher could interpret that the process of teaching and learning writing skills on descriptive text by using Wholesome Scattering Game was very effective. That's all was proved by the result of the observation that the researcher did when the researcher implemented the Wholesome Scattering Game in the study.

\begin{tabular}{|c|c|c|c|c|c|c|c|c|c|c|c|}
\hline \multirow[b]{2}{*}{ 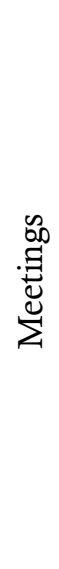 } & \multirow{2}{*}{ 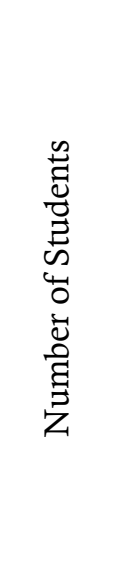 } & \multicolumn{3}{|c|}{ 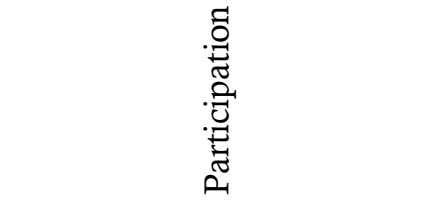 } & \multicolumn{3}{|c|}{ 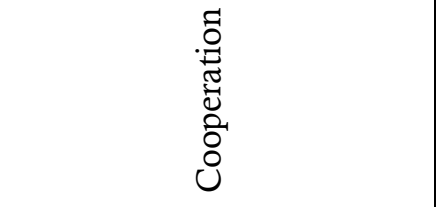 } & \multicolumn{4}{|c|}{ 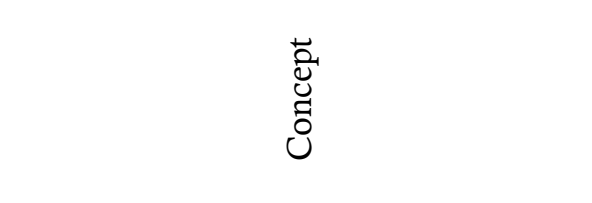 } \\
\hline & & 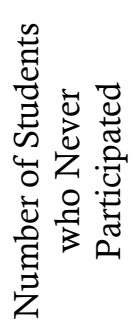 & 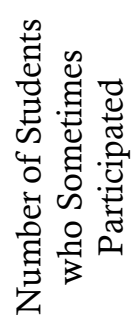 & 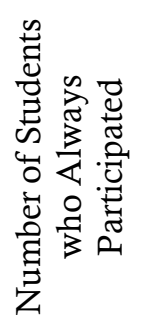 & 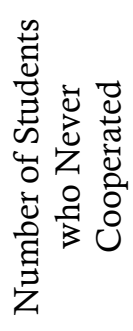 & 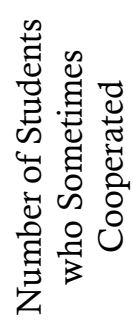 & 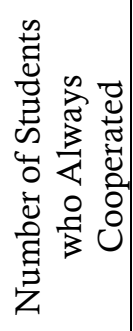 & 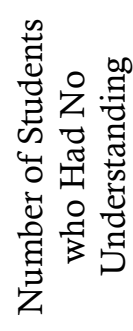 & 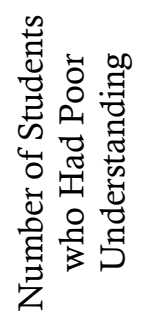 & 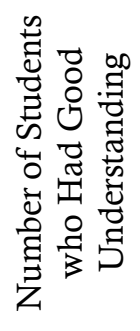 & 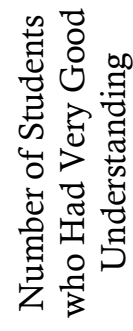 \\
\hline 1 & $(100 \%)$ & $(18 \%)$ & $(56 \%)$ & $(26 \%)$ & $(26 \%)$ & $(50 \%)$ & $(24 \%)$ & $(9 \%)$ & $(18 \%)$ & $(47 \%)$ & $(26 \%)$ \\
\hline 2 & $(100 \%)$ & $(15 \%)$ & $(59 \%)$ & $(26 \%)$ & $(26 \%)$ & $(53 \%)$ & $(21 \%)$ & $(6 \%)$ & $(15 \%)$ & $(41 \%)$ & $(38 \%)$ \\
\hline
\end{tabular}




\begin{tabular}{|c|c|c|c|c|c|c|c|c|c|c|c|}
\hline 3 & $(100 \%)$ & $(15 \%)$ & $(59 \%)$ & $(26 \%)$ & $(26 \%)$ & $(53 \%)$ & $(21 \%)$ & $(9 \%)$ & $(15 \%)$ & $(44 \%)$ & $(32 \%)$ \\
\hline 4 & $(100 \%)$ & $(12 \%)$ & $(59 \%)$ & $(29 \%)$ & $(18 \%)$ & $(56 \%)$ & $(26 \%)$ & $(9 \%)$ & $(15 \%)$ & $(44 \%)$ & $(32 \%)$ \\
\hline 5 & $(100 \%)$ & $(12 \%)$ & $(53 \%)$ & $(35 \%)$ & $(18 \%)$ & $(47 \%)$ & $(35 \%)$ & $(6 \%)$ & $(12 \%)$ & $(44 \%)$ & $(38 \%)$ \\
\hline 6 & $(100 \%)$ & $(12 \%)$ & $(53 \%)$ & $(35 \%)$ & $(12 \%)$ & $(47 \%)$ & $(41 \%)$ & $(3 \%)$ & $(9 \%)$ & $(29 \%)$ & $(59 \%)$ \\
\hline 7 & $(100 \%)$ & $(9 \%)$ & $(56 \%)$ & $(35 \%)$ & $(18 \%)$ & $(47 \%)$ & $(35 \%)$ & $(0 \%)$ & $(12 \%)$ & $(50 \%)$ & $(38 \%)$ \\
\hline 8 & $(100 \%)$ & $(6 \%)$ & $(53 \%)$ & $(41 \%)$ & $(9 \%)$ & $(56 \%)$ & $(35 \%)$ & $(0 \%)$ & $(9 \%)$ & $(26 \%)$ & $(65 \%)$ \\
\hline 9 & $(100 \%)$ & $(6 \%)$ & $(47 \%)$ & $(47 \%)$ & $(9 \%)$ & $(44 \%)$ & $(47 \%)$ & $(0 \%)$ & $(6 \%)$ & $(47 \%)$ & $(47 \%)$ \\
\hline 10 & $(100 \%)$ & $(3 \%)$ & $(44 \%)$ & $(53 \%)$ & $(6 \%)$ & $(47 \%)$ & $(47 \%)$ & $(0 \%)$ & $(3 \%)$ & $(26 \%)$ & $(71 \%)$ \\
\hline 11 & $(100 \%)$ & $(0 \%)$ & $(35 \%)$ & $(65 \%)$ & $(6 \%)$ & $(32 \%)$ & $(62 \%)$ & $(0 \%)$ & $(0 \%)$ & $(44 \%)$ & $(56 \%)$ \\
\hline 12 & $(100 \%)$ & $(0 \%)$ & $(29 \%)$ & $(71 \%)$ & $(6 \%)$ & $(32 \%)$ & $(62 \%)$ & $(0 \%)$ & $(0 \%)$ & $(74 \%)$ & $(26 \%)$ \\
\hline
\end{tabular}

From the results of observation, the researcher found that there were significant improvements in students' participation, cooperation, and concept aspects. In the students' participation aspect, the researcher could conclude that there was a good significant improvement of the students' participation in the research. Therefore, it could be inferred that most of students were able to participate in writing descriptive text. The students' participation could be seen from the steps in wholesome scattering game, namely: (1) Teacher asks three to five students to come to the board. Their task is to write down words the teacher dictate. (2) While the students at the board are doing this, the teacher asks those students who seated can produce their own arrangements of the words either on paper or in notebooks. (3) When the teacher has finished dictating the words, the teacher asks the students who are at the board return to their seats. (4) Teacher asks if anyone in the class thinks they have produced a particularly unusual arrangement of the words. If there are volunteers, the teacher asks them to display their arrangements. (6) Teacher asks the students, in pairs, to write as many sentences as possible using the words on the board. They should try to put more than one of the words in each sentence. Tell them that they have only three minutes for this. (8) Teacher asks each pair to read out its best sentence. And the last was the ninth step (9) Teacher asks the class to predict the content of the text they are about to write.

In addition, in the students' cooperation aspect, the researcher concluded that there was a good significant improvement of the students' cooperation in the research. Therefore, it could be inferred that most of students were able to cooperate each other, as they were asked to have discussion around the text and got the peer support of the groups in the research. The students' cooperation could be seen from the steps in wholesome scattering game, namely: (6) Teacher asks the students, in pairs, to write as many sentences as possible using the words on the board. They should try to put more than one of the words in each sentence. Tell them that they have only three minutes for this. (8) Teacher asks each pair to read out its best sentence. (9) Teacher asks the class to predict the content of the text they are about to write. The last, the teacher asked students to revise and edit their writing in pairs.

Furthermore, in the students' concept, the researcher inferred that there was a significant improvement of the students' concept in the study. Therefore, the researcher inferred that most of students were able to be critical learners, where the students were asked to construct sentences by using the vocabularies they have written before. This activity was applied during writing process.

From the explanation above, the researcher concluded that Wholesome Scattering Game was very effective to be implemented in improving students' writing skills.

\section{Statistical Analysis}

After accomplishing the experiment or treatment in teaching writing skills by using Wholesome Scattering Game, the researcher concluded that Wholesome Scattering Game was an effective strategy in improving students' writing skills. The researcher interpreted that there was a significant difference in writing skills between students who were taught by using Wholesome Scattering Game and those who were taught without using Wholesome Scattering Game. It could be proved from the explanation below.

Firstly, based on the students' pre-test and post-test, the result of pre-test and post-test score of experimental group who were taught by using Wholesome Scattering Game were presented as below. The lowest score in the pre-test was 50 and the highest one was 76.5. then, the average of students' pre-test was 64.35. Then in the post test, the lowest score was 60 and the highest one was 90 . Then, the average of students' post-test score was 76.83. therefore, the researcher could conclude that the scores of all students in the experimental group were was increased. In addition, based on the students' pre-test and post-test, the 
result of pre-test and post-test score control group who were taught by using non-Wholesome Scattering Game were presented as below. The lowest score in the pre-test was 57 and the highest one was 78. then, the average of students' pre-test was 64.88. and then in the post test, the lowest score was 57.5 and the highest one was 80.5. Then, the average of students' post-test score was 66.81 . Therefore, the researcher could conclude that the scores of all students in the control group were increased.

\begin{tabular}{|c|c|c|c|c|c|c|c|c|c|}
\hline \multicolumn{10}{|c|}{ Indenpendent Sample Test } \\
\hline & \multicolumn{2}{|c|}{$\begin{array}{l}\text { Levene's Test } \\
\text { for Equality of } \\
\text { Variances }\end{array}$} & \multicolumn{7}{|c|}{ t-test for Equality of Means } \\
\hline & \multirow[t]{2}{*}{$\mathrm{F}$} & \multirow[t]{2}{*}{ Sig. } & \multirow[t]{2}{*}{$\mathrm{T}$} & \multirow[t]{2}{*}{ Df } & \multirow{2}{*}{$\begin{array}{l}\text { Sig. (2- } \\
\text { tailed) }\end{array}$} & \multirow{2}{*}{$\begin{array}{c}\text { Mean } \\
\text { Difference }\end{array}$} & \multirow{2}{*}{$\begin{array}{l}\text { Std. Error } \\
\text { Difference }\end{array}$} & \multicolumn{2}{|c|}{$\begin{array}{l}95 \% \text { Confidence } \\
\text { Interval of the } \\
\text { Difference }\end{array}$} \\
\hline & & & & & & & & Lower & $\begin{array}{c}\text { Uppe } \\
\text { r }\end{array}$ \\
\hline $\begin{array}{c}\text { Equal } \\
\text { variances } \\
\text { assumed }\end{array}$ & 2.501 & .119 & -6.210 & 67 & .000 & -10.02395 & 1.61422 & -13.24594 & $\begin{array}{c}6.801 \\
96\end{array}$ \\
\hline $\begin{array}{c}\text { Equal } \\
\text { variances } \\
\text { not assumed }\end{array}$ & & & -6.192 & 63.847 & .000 & -10.02395 & 1.61882 & -13.25805 & $\begin{array}{c}- \\
6.789 \\
84\end{array}$ \\
\hline
\end{tabular}

Furthermore, based on the independent sample t-test, it was found that the mean difference between post-test in control and experimental group was 10.02395, and standard error difference was 1.61422. Then, significant (2-tailed) was 0.000, t-obtained (6.210), critical value of t-table (2.00) and degree of freedom was 67. Since the p-output or the significant (2-tailed) was 0.000 , lower than computation with significant level 0.005 and t-obtained (6.210) was higher than critical value of t-table (2.00), therefore it could be stated that there was a significant difference in pre-test between control group and experimental group. From the description above the researcher concluded that there was a significant difference between who were taught by using Wholesome Scattering Game and the students who were taught without using Wholesome Scattering Game. Therefore, the alternative hypothesis (Ha) was accepted, while the null hypothesis (Ho) was rejected.

After calculating gain point of each aspect in writing from experimental group, the researcher classified the gain points of each aspect from the highest to the lowest one, as follows:

1. Language Use aspect was the aspect with the highest gain point because most of students used word order/function, articles, pronouns, prepositions appropriately.

2. Content aspect was the second aspect with higher gain point because most of students could think critically, that's why the content of their writing were pretty good.

3. Organization aspect was the third aspect with high gain point because some students could express their idea well and they could organize logical sequencing.

4. Vocabulary aspect was the aspect with the lower gain point because most of the students were confused which vocabularies they have to use on their writing. Nevertheless, finally they had much more vocabularies after they have taught by using Wholesome Scattering Game than before. It was approved by their scores in the post test were higher than in the pre-test.

5. Mechanic aspect was the aspect with the lowest gain point because most of students did not understand yet how to use punctuation correctly and they were still confused about the idea of what paragraph is, so some of them did not write their writing on a paragraph. It was because they underestimated the simple things when the researcher shared the knowledge about mechanic.

These results were supported by some previous related studies who stated that there was a significant improvement between the students who were taught by using Wholesome Scattering Game and who were not taught by using Wholesome Scattering Game. The first previous study was conducted by Mira Santika 
entitled "The Effect of Wholesome-Scattering-Game on The Ability of the First Year Students of high school in Writing Descriptive Texts". The results of data analysis there was significant difference between pre-test and post-test because the t-test observed was higher than t-table. Therefore, that could be concluded that there was a significant difference of the scores between the student who were taught by using Wholesome Scattering Game and they who were not. It means that, Wholesome Scattering Game is a technique for teaching that gave a good effect on the ability of the first year students in writing descriptive texts. The second previous related study was conducted by Juvrianto entitled "Increasing the Writing Ability Through Wholesome Scattering Game". The findings of this study indicated that Wholesome Scattering Game could increase the students writing ability. The third previous related study was conducted by Kamilatun Nisa' entitled "Wholesome Scattering Game as A Technique for Teaching Descriptive Writing of the Seventh Graders". There were three points that can be seen in the result of this research. First was the implementation of wholesome scattering game as a technique to teach descriptive writing run well. Second, the learners' writing task result showed that the learners' writing ability was good enough. Third, the learners showed a positive response toward the implementation of wholesome scattering game. In conclusion, wholesome scattering game could be used to teach writing descriptive text for the students. It is useful to help the learners in writing descriptive text.

After analyzing the result of present study and previous studies, the researcher concluded that there were some similarities and differences between them. The main similarity was of course the use of Wholesome Scattering Game. The difference of present study and previous studies was at the kind of the research. After accomplishing the study, the researcher inferred that Wholesome Scattering Game was appropriate to be used in descriptive texts, because there were some stages that required students to be critical learners, where the students should construct sentences on their own from the vocabularies they got before from the researcher. Therefore, the researcher stated that this game or strategy should be implemented to the students in the same grade, who had same experience, knowledge, and thoughts. It was hard to implement this game or strategy to the students with different ones.

Furthermore, this game was supported by theory that stated Wholesome Scattering Game was one of the game or strategy to improve writing skills. The theory was taken from Natalie Hess, she explained that in this activity, students, on occasion not only predict the content of the passage they are about to read, but also almost duplicate sentences which actually appear in it. This game could stimulate students' ideas to write sentences. Students usually have blank ideas when they are thought material. In this game, students will be given some keywords to stimulate their brain. They were hoped can get some ideas in writing descriptive text. After accomplishing this study and considering the theory, the researcher totally agreed with the expert that stated Wholesome Scattering Game was very effective to improve students' writing skills. It was proved by the improvement of students' score in writing skill after implementing this strategy during the study.

After discussing the interpretation of the Wholesome Scattering Game and interpretation of statistical analysis result, the researcher concluded that Wholesome Scattering Game could be used as an alternative game or strategy to improve students' writing skill.

\section{Conclusions}

The research study was conducted in a public high school in Bangka Belitung Province. There were 69 students which consisted of two classes as the Experimental Group and as the Control Group. The aim of this research was to increase the students' writing skills by using Wholesome Scattering Game. As stated in the findings of the study, it could be concluded that the use of Wholesome Scattering Game was effective in improving students' writing skills. In accordance to advantages of wholesome scattering game, it has been used to stimulate students' ideas to write sentences. Morever, it was easy to prepare and students could develop their text based on keywords that have been given by the teacher. Wholesome scattering game also drilled students to know the spelling, meaning, pronunciation of all keywords. It was easier for them to write descriptive texts by using this game. During the teaching and learning process, the students showed positive responses and enjoyed the implementations of Wholesome Scattering Game. After implementing the Wholesome Scattering Game, the researcher classified and found that language use was the highest and mechanic was the lowest aspects in writing.

Furthermore, there was a significant difference between post-test scores of experimental group and posttest scores of control group. It could be shown that the mean score of the post-test in experimental group (76.83) was higher than the mean score of the post-test in control group (66.81). Then, the result of independent sample t-test stated that t-obtained (6.210) was higher than critical value of t-table (2.00) and 
the significant (2-tailed) was 0.000 , lower than computation with significant level 0.005 . The result meant that, the alternative hypothesis $(\mathrm{Ha})$ was accepted, while the null hypothesis $(\mathrm{Ho})$ was rejected. It could be concluded that there was a significant difference between students who were taught by using Wholesome Scattering Game and the students who were taught without using Wholesome Scattering Game.

After conducting a research at the high school, the researcher would like to propose some suggestions for the teachers of English and for the students, for institution and for further research. These suggestions are as follows:

Firstly, the English teachers should apply various strategies, especially in teaching writing. The teacher should be creative in using appropriate and effective strategy. One of them is Wholesome Scattering Game. The teacher also has to be creative in implementing the procedure of the strategy to avoid students' boredom. The researcher suggests the teacher to emphasize mechanic aspect in process of teaching writing.

Secondly, the students should practice English as much as possible. The students should practice more to write in English. Moreover, the students have to share their knowledge to other friends.

Thirdly, this study could be useful to others who are interested in conducting research in related issues and as a reference and comparison to conduct further studies in the same field. However, this study also requires further studies for more profound discussions.

\section{References}

Agustina, A. (2018). Improving Students' Ability In Writing Descriptive Text Through Wholesome Scattering Game T At The Tenth Grade Students Of Man Binjai In The Academic Year 2018/2019. Universitas Islam Negeri Sumatera Utara Meddan.

Babbie, E. R. (2016). The basics of social research. Cengage learning.

Hami, W. (2011). Improving students' ability in writing descriptive text through wholesome scattering game. Institute for Islamic Studies Semarang.

Hatch, E., \& Farhady, H. (1982). Research design and statistics for applied linguistics.

Indrawati, I., \& Resti, F. (2020). Using Anagram Technique to Develop Students' Vocabulary Mastery to the Seventh Grade Students. SUSTAINABLE: Jurnal Kajian Mutu Pendidikan, 3(2), 86-96.

KURNIAWATI, O. (2015). Improving Students' Speaking Ability Of Descriptive Text Through Wholesome Scattering Game (A Classroom Action Research At The Tenth Grade Of SMAN 1 Karanganyar Demak In The Academic Year 2014/2015). Universitas Muria Kudus.

Martella, R. C., Nelson, J. R., \& Marchand-Martella, N. E. (1999). Research methods: Learning to become a critical research consumer. Allyn \& Bacon.

Pratiwi, M. I. (2016). THE EFFECTIVENESS OF USING WHOLESOME SCATTERING GAME TO IMPROVE THE STUDENT'S ABILITY IN WRITING DESCRIPTIVE TEXT (Experimental Research on the Tenth Graders of SMKN 2 Demak in the Academic Year of 2015/2016). Fakultas Bahasa UNISSULA.

Sinulingga, T. M. H. (2015). THE EFFECT OF WHOLESOME SCATTERING GAME ON STUDENTSACHIEVEMENT IN WRITING DESCRIPTIVE TEXT. UNIMED.

Sugiyono, S. (2007). Metode Penelitian Kualitatif Kuantitatif dan R \& D. Bandung: Alfabeta.

Talak-Kiryk, A. (2010). Using games in a foreign language classroom.

Tavakoli, H. (2012). A dictionary of research methodology and statistics in applied linguistics. Rahnama press. 